\title{
Graduates: Perceptions Of MBA Value
}

\author{
Maynard T. Bledsoe, Meredith College, USA \\ Rebecca Oatsvall, Meredith College, USA
}

\begin{abstract}
MBA worth - who decides? Much of the current assessment comes from market driven and/or institutional perspectives. This research examines responses from Meredith College MBA graduates to determine their perceptions of the worth and value of their MBA experience.
\end{abstract}

Keywords: MBA, value, satisfaction, perception, women

\section{INTRODUCTION}

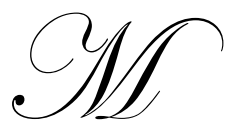

eredith College was chartered in 1891 as an undergraduate institution for women. In 1899, the first students were admitted and its first graduation occurred in 1902. From that beginning, it remained undergraduate studies only until 1983 when it began offering masters degrees in business, education and music - for women only! Much later, these degrees were opened to males.

The mission of Meredith College has been enhanced by the mission of the Graduate School and that of the MBA Program to include "teamwork, leadership, communication skills and ethical decision making"(Meredith College MBA Mission). Success of the MBA program might be indicated by congruency between college mission and alumni perceptions.

The purpose of this research is to examine information collected from MBA students who graduated during the period 1985 to 2007 . The survey instrument designed to gather the data has two distinct parts: one to address demographic material and the other which addresses "perceived value" of the MBA experience. Males were admitted to the MBA program beginning in 1999. The unique dichotomy between the periods, including/excluding males in the program, presents an opportunity to look at gender-based interpretations of MBA worth and career impact.

Interpretation of the collected, analyzed and reported data will be used to assess alumni satisfaction with the MBA program. Further, it may provide insights into changes that may or should occur to would make it more relevant in today's business climate. This study marks the beginning point for gathering alumni reactions and providing a foundation for continuing to follow both personal and professional interpretations of the value of the Meredith College MBA program.

\section{PERSPECTIVES - MARKET, INSTITUTIONAL, ALUMNI}

According to Henry Mintzberg "MBA programs train the wrong people in the wrong ways with the wrong consequences..." (Ellin, The New York Times, 6/11, 2006). A 2006 Pace University study "looking at 482 companies listed on the New York Stock Exchange, found that only 162 of them had chief executives with graduate degrees in business. The companies with chief executives who went to prestigious schools did no better than those who went to less prestigious schools... Why this was so is unclear" (Lubin School of Business, Pace University, 2006) This raises some questions whose answers may be useful in the assessment process. So where is the "value" and who decides? Much of the current assessment focuses on program, mission, goals, objectives, learning outcomes, and curriculum. These assessments come from market driven and/or institutional perspectives.

A search of the literature indicates that at least three perspectives or sources may be used to examine the worth of the MBA experience. They include Market, Institutional and Alumni information. The recruiters of major organizations represent the major market for the MBA degree. At least one article about recruiters asserted that 
student characteristics are more important than the prestige of the institution (Safón, Vincente, p. 218). Aaron Marcus, global head of recruiting for Goldman Sachs, advises graduates "While we care about your MBA degree, we care more about how you integrate yourself into the organisation (sic), what responsibilities you take on, and what value you add. Business school will give you entree to a company, but what you do when you get there matters more" (Marcus, p.10). Other common themes among articles about recruiting were that employers value team players (Alsop, Ronald "M.B.A. Track: p. B6) and would like for schools to place more value on social responsibility (Alsop, Ronald, "Talking B-School: p B7).

Another perspective on the value of the MBA experience comes from the schools that train MBAs and from the Graduate Management Admission Council (GMAC), which administers the GMAT. Most business schools use this test as part of the admissions process. Also the GMAC collects, analyzes and disseminates information about graduate business studies, including alumni views of value. The GMAC study, "MBA Alumni Perspectives Survey, 2007 Survey Report," includes "key findings" that support positive alumni perceptions of satisfaction, earnings and with making the right decision to earn an MBA degree.

(http://www.gmac.com/gmac/researchandtrends/surveyreports/)

A third perspective on the worth of an MBA degree is that of graduates. Strout found that "...an overwhelming number of business school grads feel their MBA was worth the effort" (Strout, p. 113). In order to place a value on the MBA degree, authors have used financial approaches such as the ROI concept (van Auken, Wells, and Chrysler, p. 41) as well as perception-based studies (Carmichael and Sutherland, p. 57). This research furthers the work of perception-based studies.

While the Market and Institutional perceptions are recognized as valid parts of the assessment process, the main focus of this preliminary research effort is to gain insight into the views of the Meredith College Alumni. To do this, the researchers developed a survey to collect data for analysis and interpretation. The survey has two distinct parts: questions one through six address demographic information; and questions seven through ten offer perceptions pertaining to impact, cost/benefit, and perceived value of the MBA before and after completing the program.

\section{SURVEY RESULTS: DEMOGRAPHICS}

There were 819 graduates of the Meredith MBA Program during the period May 1985 through May 2007. Of this number, 324 valid emails were available and 178 usable responses were obtained, for a response rate of 55\%. In addition to responding to the survey, alumni expressed interest in renewing affiliation within the Business School. They suggest this could occur by hiring Meredith interns, donating time to various college programs, and contributing expertise through invitations to be guest speakers for selected courses.

From 1983 to 1999 the Meredith MBA program only admitted women. Because of its early history as a single-sex program, the graduates are mostly women. Of those responding to the survey, $93.2 \%$ are female.

There was a slightly higher response rate for more recent graduates, but graduates of all years responded to the survey. The graduation dates for respondents are shown below:

Table I

\begin{tabular}{|c|c|c|}
\hline Graduation Date & Number of Responses & Percent of Total Responses \\
\hline 1985 through 1989 & 29 & $16.3 \%$ \\
\hline 1990 through 1994 & 34 & $19.1 \%$ \\
\hline 1995 through 1999 & 32 & $18.0 \%$ \\
\hline 2000 through 2004 & 38 & $21.3 \%$ \\
\hline 2005 through 2007 & 45 & $25.3 \%$ \\
\hline Total & 178 & $100.0 \%$ \\
\hline
\end{tabular}


Respondents were between 26 and 65 years old at the time of the survey. This wide range reflects the fact that some of them graduated 23 years ago, while many have more recently graduated from the MBA program. The distribution across age ranges is shown below:

Table 2

\begin{tabular}{|c|c|c|}
\hline Respondents' Current Age & Number of Responses & Percent of Total Responses \\
\hline $26-30$ & 13 & $7.3 \%$ \\
\hline $31-35$ & 36 & $20.2 \%$ \\
\hline $36-40$ & 35 & $19.7 \%$ \\
\hline $41-45$ & 31 & $17.4 \%$ \\
\hline $46-50$ & 28 & $15.7 \%$ \\
\hline $51-55$ & 20 & $11.2 \%$ \\
\hline $56-60$ & 12 & $6.8 \%$ \\
\hline $61-65$ & 3 & $1.7 \%$ \\
\hline total & 178 & $100.0 \%$ \\
\hline
\end{tabular}

Question \#5 was designed to determine present status by field of employment. Twelve percent of the respondents were employed in the field of accounting, followed by $11 \%$ in banking/finance, and $11 \%$ in health care. Next are marketing at $10 \%$, education at $8 \%$, and government at $8 \%$. After these are manufacturing at $2 \%$, religious at $1 \%$ and retail at $1 \%$.

The research design includes "Other Field" to which 36\% responded. Since this is such a large percentage, it calls for further investigation to determine specifics of respondents' field of employment. It was included as a "catch-all" category, but obviously it has greater meaning and impact and requires clarification.

Table 3

\begin{tabular}{|c|c|c|}
\hline Employment by Field & Number of Responses & Percent of Total Responses \\
\hline Accounting & 22 & $12.3 \%$ \\
\hline Banking \& Finance & 19 & $10.7 \%$ \\
\hline Education & 15 & $8.4 \%$ \\
\hline Government & 15 & $10.7 \%$ \\
\hline Health Care & 19 & $2.8 \%$ \\
\hline Manufacturing & 5 & $9.5 \%$ \\
\hline Marketing & 17 & $.6 \%$ \\
\hline Religious & 1 & $.6 \%$ \\
\hline Retail & 1 & $36.0 \%$ \\
\hline Other & 64 & $100.0 \%$ \\
\hline total & 178 & $2 \%$ \\
\hline
\end{tabular}

Respondents were asked to characterize their present position. Roughly $20 \%$ of respondents are in upper management, while one-third are in middle management and a little less than $20 \%$ are in first line or entry management positions. Also prior to a second survey, the instrument should be refined allowing for an explanation of the "other" position category which included almost $18 \%$ of respondents. The categories of retired, self employed and not employed show smaller percentages.

Table 4

\begin{tabular}{|c|c|c|}
\hline Management Level & Number of Responses & Percent of Total Responses \\
\hline Upper Management & 37 & $21.0 \%$ \\
\hline Middle Management & 58 & $33.0 \%$ \\
\hline First Line Management & 33 & $18.7 \%$ \\
\hline Retired & 1 & $.6 \%$ \\
\hline Self Employed & 11 & $6.2 \%$ \\
\hline Other & 32 & $18.2 \%$ \\
\hline Not Employed & 4 & $2.3 \%$ \\
\hline total & 176 & $100.0 \%$ \\
\hline
\end{tabular}




\section{SURVEY RESULTS: ALUMNI PERCEIVED VALUE}

Institutions offer documents, such as mission statements, goals and objectives that serve as indicators of values held. These should show the direction, intent and reason for the institution's existence. Evidence of credibility may be seen in how the various constituents perceive the institution. Three Meredith College publications which clearly demonstrate its educational values are:

\section{College Mission}

"to these ends Meredith strives to develop in students the knowledge, skills, values and global awareness necessary to pursue careers to assume leadership roles, to continue their education and to lead responsible lives of work, citizenship, leisure, learning and service"

\section{Graduate Program Mission}

"The mission of graduate programs and Meredith College is to provide: academically challenging learning in an environment that emphasizes critical thinking, leadership and application of theoretical knowledge in practical settings"

\section{MBA Mission}

“...learning experience that develops critical thinking skills...and which emphasizes teamwork, leadership, communication skills and ethical decision making”

While mission statements are valuable tools in setting benchmarks for direction and intent for an academic program, additional information may be valuable in assessing the program's worth. The Alumni response to the survey is the key component for this research effort. This information may be useful in evaluating, revising, and upgrading the MBA program. Questions are examined about alumni perceptions of the impact of the MBA program on their careers, cost/benefit analysis of the MBA program and their views of the worth of the MBA degree before embarking on the program and after its completion.

When asked about the impact of the MBA on their careers, the responses were clearly positive. Positive impacts listed include: increased communication skills, quantitative skills, ability to define and solve problems and leadership skills. Alumni responses reveal 52.8\% indicated increased communications skills, $51.7 \%$ increased quantitative skills, $59.7 \%$ increased ability to define and solve problems and $69.9 \%$ increased leadership skills. This means there is a close relationship between the program goals and alumni perceptions.

Other positive responses include: $38.6 \%$ received promotions, $48.3 \%$ received increased compensation, and $40.9 \%$ increased job satisfaction. The survey shows $31.3 \%$ changed employers, $4 \%$ decreased job satisfaction and $6 \%$ established a business.

Table 5

\begin{tabular}{|c|c|}
\hline Career Impact & Percent \\
\hline Changed Employers & $31.3 \%$ \\
\hline Received Promotion & $38.6 \%$ \\
\hline Received Additional Compensation & $48.3 \%$ \\
\hline Established Business & $6.0 \%$ \\
\hline Increased Job Satisfaction & $40.9 \%$ \\
\hline Decreased Job Satisfaction & $4.0 \%$ \\
\hline Increased Communication Skills & $52.8 \%$ \\
\hline Increased Quantitative Skills & $59.7 \%$ \\
\hline Increased Ability to Define \& Solve Problems & $69.9 \%$ \\
\hline
\end{tabular}


Question \#8 addresses cost/benefit in terms of whether rewards of obtaining the MBA were greater than the resources given up to earn the degree. Responses show $87.7 \%$ yes, $10.1 \%$ neutral and $2.2 \%$ no. The survey did not include the reasons for the answers. Cost could include things such as time, effort and money. There is no data for organizational sponsorship or other support. Likewise, there is no information to help interpret either "neutral" or "no" positions.

Questions \#9 and \#10 address respondents' perceptions of the value of the Meredith MBA prior to entering the program and after completing the program. Measuring value for any achievement can be subjective. To help reduce ambiguity, respondents had three possible options: High, Medium and Low. Responses to the question about perception of the MBA prior to entering the program were: 58.4\% High, 39.9\% Medium and 1.7\% Low. Interestingly, the percentages remained the same for perception subsequent to graduation. Combining the High and Medium views show that $98.3 \%$ of respondents were positive about the MBA program. Further research is indicated to determine rationale for the value positions.

\section{SUMMARY}

Meredith College was chartered in 1891 as a school for women. In 1983 it began an MBA program accepting women only. The first MBA degrees were awarded in 1985 and it remained women-only until 1999 when men were first allowed to enter the program. In this manner, Meredith is unique. During the 24-year period of 19852007, there were 819 MBA degrees awarded, the vast majority of which were awarded to women.

The purpose of this preliminary research was to gather data from alumni that address two issues. One has a focus on demographics and the other on perceptions. Since this marks a beginning point, it may be necessary to conduct continuing in-depth research. Even though 819 alumni exist, only 324 valid emails were obtainable. From these, 178 useable responses were gathered for a 55\% response rate. Since the program remained women-only for much of its history, it is not surprising that $93.2 \%$ of the respondents were female.

The first part of the survey findings examines alumni demographic information. There were respondents from all graduating classes, 1985 through 2007. The age range was from 26 to 65 with the largest group between 31 and 45. The question about "present position" reflects $20 \%$ of the respondents are in upper management, one third are in middle management, and almost $20 \%$ are in first-line management, with "other" showing almost $18 \%$. Obviously this category needs more investigation.

The second part of the survey looks at alumni perceptions. It reveals that communication skills, quantitative skills, increased ability to define and solve problems, and increased leadership skills are integral parts of the program. Respondents felt the program had positively affected factors such as promotion, compensation and job satisfaction. Other findings include that few had decreased job satisfaction; few established businesses and a that there were a number of job changes. From a cost/benefit perspective, most felt they received more than they gave up to obtain the degree. From a pre/post MBA value viewpoint the perceptions of the value of the MBA program were overwhelmingly positive.

Finally, the survey results reflect a positive alumni perception of the value of the MBA program. Further, it shows a high degree of congruence among the College's mission, the Graduate Program Mission, the MBA Program's Mission and what the degree holders felt they obtained from the MBA Program. This supports the notion of general alumni satisfaction with the program.

\section{AUTHOR INFORMATION}

Dr. Tony Bledsoe has taught in the School of Business at Meredith College since 1981. He teaches management, entrepreneurship and business policy to both undergraduates and MBA students. His research interests include women business owners, fraud, entrepreneurship plus case studies for teaching and learning. 
Dr. Rebecca Oatsvall, has taught in the School of Business at Meredith College since 1984. She teaches accounting and tax and directs a Study Abroad program to Italy and Switzerland. Her research interests include internal control, diversity management and case studies for teaching and learning.

\section{REFERENCES}

1. Alsop, Ronald. “M.B.A. Track: Recruiters Seek M.B.A.s Trained in Responsibility,” The Wall Street Journal. New York, NY Dec 13, 2005 p. B6.

2. Alsop, Ronald. "Talking B-School: Why Teaching Ethics Continues to Be Lacking," The Wall Street Journal. New York, NY Jun 19, 2007, p. B7.

3. "Bad for Business?” Economist. 2/19/2005, Vol 374, Issue 8414, pp. 57-58.

4. Bisoux, Tricia. "Measures of Success: With assurance of learning standards in full force, business educators evaluate how well their assessment plans are working-and where those plans should lead next," BizED. March/April 2008, pp. 22-30.

5. Carmichael, T. and Sutherland, M. "The holistic framework for the perceived return on investment in an MBA,” South African Journal of Business Management. Jun 2005. Vol. 36 Issue: 2, pp. 57-70.

6. Coleman, Marc. "Relevance versus rigour: the research debate in focus The Future Of Management Education: Business school professors have been perplexed by the question of whether MBA courses meet the needs of companies. In particular, the value of academic research is being questioned...," Financial Times. London (UK), Jan 20, 2006, p. 2.

7. Deutsch, Katrina. "MBA degrees are passport to new future," Westchester County Business Journal. 6/8 2004, Vol. 43, Issue 26, p.16.

8. $\quad$ Ellin, Abby. "Was Earning That Harvard M.B.A. Worth It?" The New York Times. June 11, 2006 p. 3.1.

9. Fisher, Dorothy M., Kiang, Melody, Fisher, Steven A. "A Value-added Approach to Selecting The Best Master of Business Administration (MBA) Program," Journal of Education for Business. Nov/Dec 2007 Vol. 83 Issue 2, pp. $72-76$.

10. Garten, Jeffrey E. "B-Schools: Only a C+ in Ethics," Business Week. 9/05/2005, p. 110.

11. Marcus, Aaron. "Entrée just for starters The Big Debate Amid Criticism From Industry And Academia About The Role And Usefulness Of The MBA: The degree is still the benchmark for many employers but achievement in the world of work is what really counts," Financial Times. London (UK); 29 Jan 2007, p. 10 .

12. Safon, Vicente. "Factors That Influence Recruiters' Choice of B-Schools and Their MBA Graduates: Evidence and Implications for B-Schools," Academy of Management Learning and Education. June 2007, Vol 6, Issue 2, pp. 217-233.

13. Schneer, Joy and Reltman, Frieda. "Time out of work: career costs for men and women US managers," Equal Opportunities International. 2006, Vol 25, Issue 4, pp. 285-298

14. Strout, Erin. "The Value of an MBA", Sales \& Marketing Management. 152.1, Nov 2000, p. 113.

15. Taylor, Katie. "MBA remains a valuable degree in the job market," Knight Ridder Tribune Business News. Washington, May 15, p. 1.

16. Van Auken, Stuart, Wells, Ludmilla Gricenko, and Chrysler, Earl. "The Relative Value of Skills, Knowledge, and Teaching Methods in Explaining the Master of Business Administration (MBA) Program Return on Investment." Journal of Education for Business. Sept-Oct 2005, pp. 41-45.

17. Wellman, Mark, Gowan, Mary A, and White, Susan C. "MBA Degree and School Tier As Human Capital: Comparative Study of MBA and Non-MBA Career Success," Academy of Management Proceedings. 2006, pp. 11-16.

18. "2007 Executive Council Survey Results Offer Industry Insights," Business Wire. New York, 3 Dec 2007

19. http:www.gmac.com/gmac/researchandtrends "MBA Alumni Perspectives Survey 2007 Survey Report" 